ROCZNIKI TEOLOGICZNE

Tom LXVII, zeszyt 6 - 2020

DOI: http://dx.doi.org/10.18290/rt.20676-6

KS. TOMASZ CHRUPEK

\title{
RELACJA OSOBOWA \\ NARZĘDZIEM DUSZPASTERSTWA MLODZIEŻY \\ NA PODSTAWIE ADHORTACJI APOSTOLSKIEJ CHRISTUS VIVIT PAPIEŻA FRANCISZKA
}

\author{
PERSONAL RELATION AS A TOOL FOR YOUTH PASTORAL CARE \\ BASED ON POPE'S FRANCIS APOSTOLIC ADHORTATION CHRISTUS VIVIT
}

\begin{abstract}
A bstract. Nowadays, a great challenge for the Church is the concern about the youth pastoral care. This urgent matter was also noticed by Pope Francis in the Apostolic Exhortation Christus vivit. According to this document, it is possible to create a particular pastoral strategy to work with young people. In accordance with the Pope's opinion, this concern about young people should be expressed in deep, personal relationships that are built on a true authority. A very significant factor in the process of Christian formation is the role of an appropriate leader and community, which creates an environment of faith that leads to a meeting with God. Man is a relational being. Therefore, thanks to relationship with other people, one can lead others to meet the Lord. Caring for the youth is not reserved only for individuals, but also for all environments that have an impact on young people. It is only the commitment of everyone that will help to construct pastoral and effective youth ministry.
\end{abstract}

Key words: youth; Christus vivit; personal relationship; pastoral care; leader; upbringing; family; intergenerational relations.

Troska duszpasterska o młodych jest naglącym wyzwaniem Kościoła. Ciągłość wiary i tradycji chrześcijańskiej, a więc młodość i aktualność samej wspólnoty wierzących, będzie zależała od odważnej decyzji młodego pokolenia, gotowego podjąć się trudnego zadania przyjęcia i aktualizacji wiary na miarę tych czasów, w których przyjdzie im żyć.

Ks. mgr lic. Tomasz ChruPEK - student Teologicznego Studium Licencjackiego Katolickiego Uniwersytetu Lubelskiego Jana Pawła II; adres do korespondencji: e-mail: tomek-91_1991@tlen.pl; ORCID: http://orcid.org/0000-0003-1282-8385

Rev. TOMASZ CHRUPEK - student of pastoral theology at the John Paul II Catholic University of Lublin; address for correspondence: e-mail: tomek-91_1991@tlen.pl; ORCID: http://orcid.org/0000-0003-1282-8385 
Kościół nie może lekceważyć młodości, którą uświęcił sam Chrystus (por. ChV 22). Jego okres dojrzewania był czasem ,formowania się”, który doprowadził Go do najważniejszej misji w dziejach świata (por. ChV 27). W przekonaniu papieża Franciszka: „W tym okresie życia ludzie młodzi są powołani, aby zaprojektować sobie przyszłość, nie odcinając korzeni, by budować niezależność, ale nie samotność" (ChV 137).

Powaga sytuacji związana z troską o przyszłość Kościoła skłania do refleksji nad aktualną kondycją duchową młodzieży w Polsce. Jest wiele niepokojących przesłanek, które domagają się dogłębnej analizy oraz konkretnych wniosków, by nie stracić tych, od których zależy przyszły los Kościoła. W badaniach sondażowych nad młodzieżą już od wielu lat obserwuje się spadek poziomu religijności. Aktualne wyniki badań potwierdzają, że jest to istotny trend odzwierciedlający zmiany w naszym społeczeństwie, ukazujący, iż polska młodzież jest w coraz mniejszym stopniu religijna ${ }^{1}$. Największa część przebadanej przez CBOS młodzieży (60\%) deklaruje, że wierzy w Boga, przy czym tylko 37\% nie ma co do Jego istnienia wątpliwości. Porównując aktualne wyniki do pomiarów z lat 2013 i 2016, można zauważyć, iż obniżył się udział osób deklarujących wiarę w Boga (wtedy wynosił odpowiednio: $71 \%$ i $68 \%)^{2}$. Warto zwrócić uwagę na to, że w najnowszym badaniu po raz pierwszy zrównały się odsetki młodych biorących udział w praktykach religijnych co najmniej raz w tygodniu (35\%) i nie biorących w nich udziału wcale $(35 \%)^{3}$, przy czym w pierwszym wskaźniku zaznaczył się spadek, a w drugim niestety wzrost. Szczególnym wyzwaniem dla duszpasterstwa jest więc religijna socjalizacja młodego pokolenia Polaków. Ogólnopolskie badania socjologiczne wskazują na słabnącą rolę religii w życiu codziennym młodych Polaków, do tego stopnia, że nie można już mówić o stabilności religijnej w pokoleniu młodzieży. Coraz bardziej staje się uprawomocniona teza o przyspieszonej sekularyzacji

Dane statystyczne nie są dogmatem, są jednak przydatne w pracy duszpasterskiej, gdyż przemawiają do wrażliwości duszpasterzy zatroskanych o dobro młodych ludzi, jak widać - dość często religijnie zagubionych lub niezdecydowanych. W obecnej sytuacji społeczno-religijnej młodzieży w Polsce zadaniem pastoralistów jest poszukiwanie nowych narzędzi formacji religijnej młodzieży. Dotychczasowe duszpasterstwo, oparte na wielkich zgromadzeniach ludzi młodych, nawet

\footnotetext{
${ }^{1}$ Antoni GŁowackI, „«Religijność młodzieży i uczestnictwo w lekcjach religii w szkołach». Komunikat z badań CBOS nr 43/2019”, w Młodzież 2018, red. Mirosława Grabowska i Magdalena Gwiazda (Warszawa: CBOS, 2019), 147.

${ }^{2}$ Glowacki, Religijność młodzieży, 148.

${ }^{3}$ Glowacki, Religijność młodzieży, 151.

${ }^{4}$ Kazimierz ŚwiĘS, „Uwarunkowania duszpasterstwa parafialnego w Polsce na początku XXI wieku”, Teologia i Człowiek 47, nr 3 (2019): 87.
} 
w Polsce przechodzi powoli do lamusa. Jedną z nowych propozycji pastoralnych zaadresowanych do współczesnej młodzieży może być natomiast wykorzystanie dojrzałej relacji osobowej duszpasterza z młodzieżą. To zagadnienie jest przedmiotem refleksji niniejszego opracowania, a jego problem można wyrazić za pomocą pytania, w jaki sposób wykorzystać relacje osobowe do rozwijania efektywnego duszpasterstwa młodzieży. Głównym źródłem tej refleksji jest nauczanie papieża Franciszka, a szczególnie jego posynodalna adhortacja apostolska Christus vivit, która wiele miejsca poświęca funkcji dojrzałych relacji osobowych w formacji religijnej młodego pokolenia chrześcijan.

\section{RELACJE OSOBOWE NA DRODZE SPOTKANIA Z BOGIEM}

Termin „relacja” (łac. relatio) wywodzi się z filozofii i w języku metafizyki oznacza odniesienie się jednego bytu do drugiego 5 . Jeśli do siebie odnoszą się osoby ludzkie, mówimy wówczas o relacjach osobowych. W ścisłym sensie o takiej relacji można mówić dopiero wtedy, gdy obydwie osoby (korelaty relacji) traktują siebie w sposób personalny, a nie instrumentalny ${ }^{6}$. Relacje osobowe są także podstawą powstawania wszelkich wspólnot i ich cechą jest wzajemne oddziaływanie ${ }^{7}$. Wiedza o relacjach osobowych może okazać się bardzo przydatna w duszpasterstwie i należy z niej obficiej niż dotychczas korzystać.

Współczesna młodzież zachwyca się najnowszymi wynalazkami techniki medialnej, które bardzo absorbują jej czas. Ponadto, jak zauważa Franciszek, w niektórych środowiskach młodzieżowych coraz bardziej szerzy się fascynacja zachowaniami ryzykownymi, które przyciągają swą nowoczesnością (por. ChV 82). Jest jednak jedna rzeczywistość, której nikt nie może zabrać Kościołowi zatroskanemu o młodzież, mianowicie autentyczna relacja międzyludzka. Młodzi bardzo optymistycznie reagują wciąż na ludzi, którym prawdziwie na nich zależy i którzy chcą spędzić z nimi czas ${ }^{8}$. To właśnie w relacji osobowej papież Franciszek widzi skuteczne narzędzie formacji chrześcijańskiej młodzieży.

Źródłem długofalowego i pozytywnego oddziaływania są więc ludzie, a konkretnie relacje między nimi. Papież Franciszek wspomina, że współczesne

\footnotetext{
${ }^{5}$ Marian Wolicki, Relacje osobowe (Sandomierz: Wydawnictwo Diecezjalne i Drukarnia, 2008): 11.

${ }^{6}$ Wolicki, Relacje osobowe, 12.

${ }^{7}$ Wolicki, Relacje osobowe, 107.

${ }^{8} \mathrm{Jim}$ Burns, Owocna postuga wśród młodzieży. Czyli jak towarzyszyć młodym, tł. Krzysztof Zabawa (Gubin: Wydawnictwo Przystanek Jezus, 2017), 41.
} 
przemiany prowadzą ludzi, zwłaszcza młodych, do poszukiwania przynależności (por. EG 105). Wniosek ten wyprowadza z przykładu samego Jezusa, który nie był samotnym nastolatkiem. Jego relacja z ludźmi, wśród których dorastał, była całkiem zwyczajna, a zarazem ukierunkowana wertykalnie ku Bogu Ojcu (por. ChV 28). W tym kontekście duszpasterstwo młodzieży powinno podjąć wysiłek budowania środowiska chrześcijańskiego. Chodzi o stworzenie takiej przestrzeni, która zgromadzi ludzi nie tylko podzielających tę samą wiarę, ale starających się nią odważnie dzielić z każdym9 . Franciszek nazywa tę procedurę „tworzeniem domu”, w którym ważni są jednakowo wszyscy (por. ChV 217). Szkoła (por. ChV 221), rodzina (por. ChV 262), środowiska młodzieżowe (por. ChV 151) powinny najpierw stać się miejscem spotkania z człowiekiem, by dzięki niemu tworzyć relację z Bogiem.

Można postawić pytanie, czy w obecnych czasach, w których więzi międzyludzkie bywają zdeformowane, a relacje między duszpasterzami i młodymi atakowane, często wykrzywiane i coraz bardziej proceduralnie obciążane, ta forma duszpasterstwa ma nadal sens? Papież Franciszek nawiązuje to tego trudnego tematu, doceniając przede wszystkim pracę większości kapłanów wypełniających swą posługę wiernie i hojnie (por. ChV 100). Niemniej jednak relacja międzyosobowa jako metoda duszpasterstwa nie jest ani nowa, ani odkrywcza. Trzeba zatem zadać pytanie, jak ją stosować i na czym polega jej skuteczność?

Duszpasterstwo służy urzeczywistnianiu Kościoła w aktualnej sytuacji historycznej, społecznej i kulturowej. Dlatego zaangażowani w duszpasterstwo powinni korzystać również z dorobku współczesnych nauk ekonomicznych, zajmujących się zagadnieniami związanymi z przekazywaniem dóbr oraz relacjami z ich adresatami. Jedną z możliwości jest korzystanie z tzw. marketingu relacji, który skupia się na tworzeniu i podtrzymywaniu relacji handlowca $\mathrm{z}$ klientem ${ }^{10}$. Ta propozycja pozwala zrozumieć, na czym może w istocie polegać aktualna metoda relacji osobowej w duszpasterstwie młodzieży.

Marketing relacji polega na tworzeniu długotrwałych relacji sprzedawcy z klientem, co przynosi większe korzyści niż skupianie się na pojedynczych transakcjach. Jednym z założeń marketingu relacyjnego jest wzmożona uwaga na jakość obsługi klienta, ponieważ od tego sposobu, w jaki zostanie on obsłużony, zależy, czy wróci ponownie ${ }^{11}$. Kluczem więc skutecznej więzi w duszpasterstwie jest relacja niepozbawiona wysokiej jakości. Do tego nawiązuje papież Franciszek, apelując do ludzi

\footnotetext{
${ }^{9}$ Marek FiaŁkowski, „Papieża Franciszka inspiracje dla duszpasterstwa młodzieży”, Polonia Sacra 20, nr 4(2016): 92.

${ }^{10}$ Dariusz LIPIEC, „Marketing a duszpasterstwo”, Teologia Praktyczna 16(2015): 7.

${ }^{11}$ LiPIEC, „Marketing a duszpasterstwo”, 9.
} 
dorosłych, by nie zatracali ducha młodzieńczego, zdolnego do wejścia z nimi w prawdziwe i głębokie relacje. „Są pewne sprawy - zauważa papież - które trzeba «ustatkować» $\mathrm{z}$ biegiem lat, ale to dojrzewanie może współistnieć z ogniem, który się odnawia, z sercem zawsze młodym" (ChV 160). Autentyczne relacje zawsze powinny opierać się na autorytecie, jednak nie tylko formalnym, ale przede wszystkim osobowym, ukształtowanym na fundamencie więzi osobowej ${ }^{12}$. Dzięki temu, że Kościół porzuca sztywne schematy i otwiera się na słuchanie młodych, widząc, jakie mają potrzeby, sam się ubogaca i pozwala młodym na wniesienie do wspólnoty ich wkładu (por. ChV 65). To dzięki budowaniu relacji międzyludzkich i funkcjonowaniu w różnorodnych rolach odbywa się proces kształtowania osobistej tożsamości ${ }^{13}$.

\subsection{PRZYCZYNY KRYZYSU RELACJI OSOBOWYCH}

Podejmując refleksję na temat relacji osobowych jako narzędzia duszpasterstwa młodzieży, należy także zwrócić uwagę na przyczyny kryzysu tych relacji. Głównym powodem kryzysu relacji jest grzech, który osłabia lub zrywa więź z Bogiem (KKK 1855), przez co oddala ludzi od siebie wzajemnie (por. ChV 13). Według Franciszka w młodych sumieniach można odnaleźć wiele porażek czy smutnych wspomnień. Bardzo często są to rany niezrealizowanych pragnień, dyskryminacji, niesprawiedliwości, braku poczucia bycia kochanym i uznanym (por. ChV 83). Ponadto rany moralne, ciężar własnych błędów i poczucie winy sprawiają, że młodzi czują się niegodni relacji, więc się nie ubiegają o jej zawiązanie. W takiej sytuacji papież wskazuje na osobę Chrystusa - Lekarza dusz ludzkich, który w każdej sytuacji oferuje człowiekowi swoją przyjaźń, dając ulgę i ukojenie. Zadaniem Kościoła jest jedynie bycie narzędziem Chrystusa w drodze ku wewnętrznemu uzdrowieniu każdego poranionego człowieka (por. ChV 83).

Kolejny powód kryzysu wynika z poprzedniego. Gdy młody człowiek nie odnajduje wsparcia u bliźniego, ucieka w świat wirtualny, w którym jest mu bardzo wygodnie, gdzie cieszy się anonimowością, gdzie kreuje swoją sylwetkę w taki sposób, by podleczyć własne kompleksy. Chodzi tutaj o środowisko cyfrowe, w którym Internet i sieci społecznościowe stworzyły nowy sposób komunikowania się i tworzenia więzi (por. ChV 87). W rzeczywistości jest to także środowisko naznaczone samotnością, manipulacją i przemocą. Franciszek potrafi dostrzec oczywiście dobre

\footnotetext{
${ }^{12}$ Janusz MARIAŃSKI, Żyć parafią (Wrocław: Wydawnictwo Wrocławskiej Księgarni Archidiecezjalnej, 1984), 109.

${ }^{13}$ Jerzy Herberger i Monika KozŁowsKa, „Relacje interpersonalne z perspektywy psychologii rozwoju człowieka", Relacje. Studia z Nauk Społecznych nr 4, 2017, 44.
} 
strony tego środowiska (por. ChV 87), ale przestrzega przed zagrożeniem rozwoju nieautentycznych relacji międzyludzkich przez utratę kontaktu z rzeczywistością (por. ChV 88). Zagadnienie wpływu treści przemocowych w multimediach na eskalację zachowań społecznych w życiu codziennym młodzieży jest obszarem ciągłej analizy badawczej ${ }^{14}$. Niewątpliwie należy wciąż poszukiwać bardziej skutecznego przeciwdziałania wobec tego zjawiska między innymi w duszpasterstwie młodzieży.

Ostatni powód kryzysu relacji w środowisku ludzi młodych jest niejako konsekwencją dwóch poprzednich. Ludzka słabość, utwierdzanie się we własnych wadach, złych nawykach, egoizmie lub chorobliwej wygodzie, prowadzi do pokusy izolacji, która staje się bezpieczną kryjówką (por. ChV 109). Brak wspólnoty, jak zauważa Franciszek, sprawia, że młody człowiek przestaje walczyć z własną pożądliwością oraz z zasadzkami złego. Nigdy nie można pozwolić na to, by młodzież zamknęła się we własnej samotności. W takiej sytuacji tracą oni kontakt ze światem i wewnętrzną siłę (por. ChV 110). Różne przejawy wewnętrznych zranień, fascynacja cyfrową rzeczywistością, a także samotność, połączona z izolacją od wspólnoty ludzi wierzących, stanowi duże wyzwanie dla duszpasterzy i tych wszystkich, którym zależy na dobru młodego pokolenia.

\subsection{ZNACZENIE RELACJI RODZINNYCH I MIĘDZYPOKOLENIOWYCH}

Na początku należy nadmienić, iż refleksja nad relacjami osobowymi dotyczącymi środowiska rówieśniczego oraz instytucjonalnego młodzieży zasługuje na pogłębioną analizę w osobnym artykule. W niniejszym opracowaniu rozwinięta zostanie jedynie kwestia rodzinnej relacji osobowej młodzieży w aspekcie międzypokoleniowym. Temu zagadnieniu papież Franciszek poświęca wiele uwagi w adhortacji apostolskiej Christus vivit ze względu na wpływ tej komórki społecznej na relację ludzi młodych z Bogiem.

Wychodząc od doświadczenia osoby Jezusa Chrystusa, papież Franciszek zwraca uwagę na relację Syna z Ojcem. Nasz Zbawiciel przynależał do konkretnej rodziny, w której wzrastał i przygotowywał się do działalności publicznej. Wśród tych opisów dostrzegamy także, jak był poddany swym rodzicom (por. Łk 2, 51). To dzięki tym relacjom Jezus pogłębiał rozumienie własnej tożsamości (por. Łk 2, 52). Biorąc więc pod uwagę ogromny wpływ rodziny na formowanie właściwej więzi ze

\footnotetext{
${ }^{14}$ Andrzej BaŁandynowicz, „Cyberprzestrzeń jako facylitacja degeneratywnych zachowań młodzieży”, w Młodzi. Przeciw czemu się buntuja?? Czego pragna?? Co budują?, red. Łukasz Kwadrans, Ewa Sowa-Behtane i Bogdan Stańkowski (Kraków: Wydawnictwo Naukowe Akademii Ignatianum, 2018), 174.
} 
Stwórcą, Franciszek podkreśla, by w duszpasterstwie młodzieży nie tworzyć projektów, które izolują młodych od rodziny i świata, lecz by pogłębiały i umacniały te relacje (por. ChV 30). Ta przestrzeń jest jedną z najistotniejszych, gdyż od niej zależy kształtowanie się dalszej przestrzeni życiowej ${ }^{15}$.

Komplementarne duszpasterstwo młodzieży oraz jej rodzin jest istotnie proroczym apelem papieża Franciszka, trafiającym w potrzeby obecnego czasu, który powinien spotkać się z przychylnym przyjęciem przez duszpasterzy. Dom jest miejscem, w którym można odnaleźć bezpieczeństwo, oparcie i autorytet. Grupa rówieśnicza zaś kształtuje wzory zachowań, style bycia, sprzyja wymianie poglądów. Wyniki badań sondażowych CBOS z 2018 roku uświadamiają jednak, że rówieśnicy rzadziej niż kiedyś pełnią rolę autorytetu. Tym wielkim zaufaniem cieszą się najczęściej rodzice, przede wszystkim matka (57\%), rzadziej ojciec $(42 \%)$. Mniej także zależy im na aprobacie ze strony chłopaka lub dziewczyny $(27 \%)$ oraz przyjaciół $(21 \%)$. Najrzadziej autorytetem staje się rodzeństwo $(8 \%)$ lub koledzy i koleżanki $(6 \%)^{16}$. Są to informacje bardzo budujące i dające nadzieję, otwierające nowe perspektywy i szanse rozwoju. Równocześnie jest to nadal bardzo słabo zagospodarowany obszar duszpasterstwa, który mógłby przynieść błogosławione owoce. Dlatego jakże aktualne stają się przestrogi Franciszka, który w swoim dokumencie podkreśla, że „rodzina powinna być pierwszą przestrzenią akompaniamentu" (ChV 242). Duszpasterstwo młodzieży domaga się uprzedniej troski o dom rodzinny, aby stawał się domem zbudowanym na skale, czyli na Chrystusie (por. Mt 7, 24-25). Synod Biskupów z 2018 roku podkreślił, że rodzina nadal jest dla młodych ważnym punktem odniesienia, co potwierdzają również aktualne wyniki badań sondażowych przeprowadzanych w Polsce. Młodym ludziom wciąż zależy na więzach rodzinnych, które przy odpowiednim towarzyszeniu Kościoła, mogłyby stać się piękną i wiarygodną drogą ku nawiązaniu relacji z Bogiem. W tym względzie również jest wiele do zrobienia w duszpasterstwie młodzieży.

Porównanie wyników badań sondażowych z lat 1998 i 2018 wskazuje na coraz większą obojętność rodziców wobec obowiązku uczestnictwa ich dzieci w niedzielnej Mszy Świętej (od 1998 do 2018 roku wskaźnik ten zmniejszył się aż o 22 punkty procentowe - z 52\% do 30\%). Częściej też oczekiwania rodziców dotyczące obowiązku chodzenia do kościoła deklaruje młodzież żyjąca w pełnych

\footnotetext{
${ }^{15}$ Ewa KARMOLIŃSKA-JAGODZIK, „Przestrzeń międzygeneracyjna - relacje młodzieży z rodzicami”, Studia Edukacyjne nr 47, 2018, 301.

${ }^{16}$ Beata RoguSKA, „Dom rodzinny, rodzice i rówieśnicy w opiniach młodego pokolenia Polaków”. Komunikat z badań CBOS nr 43/2019, w Młodzież 2018, 22.
} 
rodzinach $(35 \%)$ niż młodzież mieszkająca z jednym z rodziców $(17 \%)^{17}$. Również ojcowie Synodu Biskupów z 2018 roku podkreślili, że wzrost liczby separacji, rozwodów, powtórnych związków i niepełnych rodzin może powodować w młodych osobach kryzys tożsamości i wiary, co niewątpliwie domaga się jakiejś duszpasterskiej terapii (por. ChV 262).

Współczesna młodzież może postrzegać rodzinę jako środowisko trudne, pełne uciemiężenia. Prowadzi to do jej odrzucenia pod naciskiem globalnej kultury, przy czym pozbawia w ten sposób punktów odniesienia do innych osób, a także do Boga (por. ChV 80). W tej trudnej sytuacji pewnym wyzwaniem dla duszpasterstwa jest wspieranie procesu budowania i rozwoju relacji międzypokoleniowych w rodzinach. $Z$ pewnością pogłębienie relacji młodych osób ze starszym pokoleniem byłoby innowacyjnym, a zarazem korzystnym działaniem duszpasterskim ${ }^{18}$. Tym bardziej że Polska w porównaniu z innymi krajami Europy charakteryzuje się nieco bliższymi relacjami międzypokoleniowymi oraz występowaniem dosyć jeszcze dużego odsetka rodzin wielopokoleniowych ${ }^{19}$.

W przekonaniu papieża Franciszka dziadkowie często mają decydujący wpływ na uczucia i wychowanie religijne wnuków (por. ChV 262). Młodość jest czasem energicznego patrzenia w przyszłość. Tej optymistycznej postawie zagraża jednak skłonność do zapominania o przeszłości. Pomaganie ludziom młodym w odkrywaniu życiowego bogactwa przeszłości pozwoli zakorzenić się w wartościach ponadczasowych, których istotną częścią jest wiara (por. ChV 187). Chodzi o przyjęcie postawy otwarcia się na życiową mądrość, która jest przekazywana z pokolenia na pokolenie (por. ChV 190). Światu nigdy nie wyszło na dobre zrywanie więzi między pokoleniami, przed czym przestrzega Franciszek w swej adhortacji: „, ... ] jest to łabędzi śpiew przyszłości bez korzeni, bez zakorzenienia. Jest to kłamstwo, które chciałoby, byś uwierzył, że tylko to, co nowe, jest dobre i pięknie" (ChV 191). Ważną zasadą w przekazywaniu tradycji przodków jest jednak przywoływanie zwłaszcza tych aspektów z przeszłości, które w znaczący sposób ujawniają się w obecnej sytuacji ${ }^{20}$.

Istnienie relacji międzypokoleniowych sprawia, że we wspólnotach chrześcijańskich jest obecna zbiorowa pamięć, przekazywana z pokolenia na pokolenie jako dziedzictwo dla następców i gwarant przyszłości. Papież Franciszek porównuje je

\footnotetext{
${ }^{17}$ RogusKa, Dom rodzinny, 30.

${ }^{18}$ FrancisZeK, „Spotkanie z polskimi biskupami, Kraków - Katedra, 27.07.2016”, w Błogosławieni miłosierni. Stowa do młodych (Kraków: Wydawnictwo M, 2016), 38.

${ }^{19}$ Anna RUDNIK, ,Relacje międzypokoleniowe w rodzinie - perspektywa gerontologiczna”, w Relacje międzypokoleniowe we współczesnych polskich rodzinach, red. P. Szukalski, Wydawnictwo Uniwersytetu Łódzkiego, Łódź 2014, s. 43.

${ }^{20}$ KaRMOLIŃSKA-JAGODZIK, Przestrzeń międzygeneracyjna, 301.
} 
do korzenia, symbolizującego wspólną drogę młodych i starszych (por. ChV 199). Nawiązanie zaś do proroctwa Joela: „Starcy wasi będą mieć sny, a młodzieńcy wasi będą mieć widzenia" (por. Jl 3, 1), stanowi perspektywiczny plan harmonijnej relacji między kolejnymi pokoleniami, w jakim ludzie młodzi, zakorzenieni w marzeniach starszych, „mogą mieć wizje, które otwierają im horyzonty i ukazują nowe drogi" (ChV 193).

Relacje międzypokoleniowe, zachodzące w głównej mierze w rodzinach, warto jednak przedłużyć w działalności charytatywnej wyrażanej przez wolontariat (por. ChV 225). Dzięki niemu młode pokolenie wyrabia w sobie wrażliwość na różne formy ludzkiej biedy, zwłaszcza ubóstwo i wielorakie ograniczenia wieku senioralnego, ucząc się odpowiedzialności względem drugiego człowieka ${ }^{21}$. Posługa charytatywna młodzieży wobec osób starszych powinna być wciąż aktualną przestrzenią duszpasterskiej troski, dzięki której przekaz wartości i wiary może zachować swoją ciągłość i przyczynić się do ożywienia relacji między pokoleniami.

\section{OCZEKIWANE I NIEOCZEKIWANE CECHY DUSZPASTERZA MŁODZIEŻY}

Papież Franciszek w adhortacji apostolskiej Christus vivit znacznie rozszerza pojęcie osoby odpowiedzialnej za duszpasterstwo młodzieży. Przypomina, że ta funkcja nie może skupiać się tylko wokół pojedynczych jednostek, ale jest to zadanie wspólnoty wielu osób mających wpływ na młodzież (por. ChV 202, 243). W epoce powszechnych przeobrażeń społecznych i technologicznych musiało ulec zmianie rozumienie przywództwa, pojmowanego teraz jako pewien zespół zachowań, których oczekuje się od wszystkich ${ }^{22}$.

Zdaniem Franciszka odpowiedzialność za formację chrześcijańską młodzieży nie może być zawężona i zarezerwowana jedynie dla księży i osób konsekrowanych. Ludzie świeccy także powinni być do niej włączeni (por. ChV 246). Od wszystkich jednak oczekuje się kompetentnego przygotowania i zaangażowania w osobistą formację. W celu określenia odpowiedzialnych za formację, używa on głównie dwóch ${ }^{23}$ terminów: „lider”24 (por. ChV 231) oraz „przewodnik” (por. ChV 246).

\footnotetext{
${ }^{21}$ Por. Wiesław PrzYGodA, „Wolontariat w służbie solidaryzmu społecznego dzieci i młodzieży”, Zeszyty Formacji Katechetów nr 4(2017), 29-36.

${ }^{22}$ Chris Lowney, Lider Papież Franciszek, tt. Marek Chojnacki (Kraków: Wydawnictwo WAM, 2014), 45.

${ }^{23}$ Rzadziej: „ojciec” i ,pasterz” (ChV 67).

${ }^{24}$ Dogłębne zrozumienie tego pojęcia w ujęciu papieża Franciszka umożliwia lektura książki Ch. Lowneya pt. Lider Papież Franciszek. Studium to jest przeprowadzane z perspektywy managera
} 
Są to bardzo spójne i trafne pojęcia, o wiele głębsze znaczeniowo niż np. pojęcie „kierownika”, które oznacza podejmującego czynności w wyniku zlecenia czy ze względu na wykonywany zawód. W pojęciu lidera lub przewodnika tkwi prawdziwe „przymierze” podkreślające ważność tych osób, za których bierze się odpowiedzialność ${ }^{25}$. Służba, którą podejmują liderzy lub przewodnicy, ma charakter bardziej koordynacyjny i angażujący, oparty na towarzyszeniu, a nie dominowaniu (por. ChV 247). Dlatego osoba lidera nie powinna być nigdy w opozycji do wspólnotowej odpowiedzialności za młodych. $\mathrm{Z}$ kolei brak lidera powoduje, że grupa działa chaotycznie i jest pozbawiona wizji przyszłości ${ }^{26}$.

Lektura adhortacji Christus vivit rodzi aktualne pytania dla liderów odpowiedzialnych za duchowy wzrost młodzieży. Najogólniej można wskazać dwa pytania: jakimi cechami pozytywnymi powinien odznaczać się prawdziwy przewodnik młodych oraz czego powinien się wystrzegać, uwzględniając przy tym najczęściej popełniane błędy.

\subsection{POZYTYWNE CECHY PRZEWODNIKA MŁODZIEŻY}

Zdaniem papieża Franciszka oprócz zwykłej pracy duszpasterskiej prowadzonej według określonych schematów czymś istotnym jest stworzenie przestrzeni dla „młodzieżowego duszpasterstwa ludowego", które charakteryzuje się odrębnym stylem, rytmem i metodologią. To duszpasterstwo, szersze i bardziej elastyczne, powinno dawać pobudzający impuls w różnych miejscach, gdzie przebywają młodzi (por. ChV 230). Ze stylu „duszpasterstwa ludowego” wynika także postawa, którą powinien cechować się sam lider. Duchowy przewodnik nie może być elitarny, czyli stawiany na piedestale i zamknięty w małych grupach osób wybranych, ale ludowy, czyli dostrzegający uczucia ludzi, aby stawać się ich rzecznikami i działać na rzecz ich promocji. Liderami ludowymi są zatem ci, którzy mają umiejętność angażowania wszystkich, włączając także najuboższych, słabych, ograniczonych i zranionych (por. ChV 231).

Franciszek bynajmniej nie ignoruje głosu samych młodych i przytacza ich opinie o cechach, których oczekują od osób im towarzyszących:

i znanego teoretyka przywództwa, który w osobie papieża Franciszka dostrzega uniwersalny model lidera. Książka jest dowodem na to, iż sugestie papieża wynikają z jego osobistego doświadczenia.

${ }^{25}$ David TAYLOR, Lider bez maski. Prawdziwa droga do sukcesu, tł. M. Werbanowska (Warszawa: Wolter Kluwer Polska, 2009), 72.

${ }^{26}$ Lucyna BAKIERA i Barbara HARwAS-NAPIERAŁA, Wzory osobowe w rozwoju czlowieka (Poznań: Wydawnictwo Naukowe UAM, 2016), 34. 
Od przewodnika w wierze oczekuje się, że będzie wiernym chrześcijaninem, zaangażowanym w Kościele i w świecie, stale będzie dążył do świętości, będzie powiernikiem, który nie wydaje osądów, będzie aktywnie słuchał potrzeb młodych ludzi i na nie odpowiadał, będzie osobą głęboko kochającą i świadomą siebie, a także będzie znał swoje ograniczenia oraz radości i cierpienia związane z duchową wędrówką. Szczególnie istotną cechą przewodnika jest umiejętność uznania swojego człowieczeństwa - tego, że popełnia błędy i że nie jest się człowiekiem bez skazy, ale grzesznikiem, któremu przebaczono [...]. Przewodnicy powinni iść razem z nimi, pozwalając im być aktywnymi uczestnikami wędrówki. Powinni uszanować wolność związaną z procesem rozeznawania i zapewnić młodym narzędzia niezbędne na tej drodze. Przewodnik powinien wierzyć całym sercem w to, że młody człowiek jest zdolny do uczestnictwa w życiu Kościoła. Powinien pielęgnować ziarna wiary w młodych, nie oczekując natychmiastowych owoców działania Ducha Świętego (ChV 246).

Ojciec święty liczy się więc ze zdaniem młodzieży, umiejętnie „czyta” ich potrzeby religijne i duchowe w kontekście współczesnych uwarunkowań życia ludzi młodych w przekroju globalnym. Papież często wraca do ich oczekiwań i postulatów, rozwija je, by podkreślić tym samym ich ważność i doniosłość.

Lider w zamyśle Franciszka to osoba, która ma odwagę być innym. Nie „dziwakiem", ale kimś potrafiącym ukazywać drugim marzenia, jakich nie oferuje ten świat (por. ChV 36). Stanie się to dopiero możliwe w atmosferze bliskości młodych oraz osób za nich odpowiedzialnych. Jest to istotna cecha prawdziwego lidera, która niestety w dzisiejszych czasach ulega wykrzywieniu i zniesławieniu. Bliskość nie ma znaczenia tylko pejoratywnego. W ujęciu Franciszka bliskość oznacza zasłuchanie w głos młodzieży (por. ChV 28), co podkreślał wcześniej w adhortacji Evangelii gaudium (por. EG 105). Bliskość to również prowadzenie człowieka do sakramentów, a także towarzyszenie mu w drodze, by uchronić przed upadkiem i udzielaniem wsparcia wtedy, gdy błądzi ${ }^{27}$.

Ważną predyspozycją lidera jest także umiejętność dostrzegania dobra wśród młodzieży, nawet tego najmniejszego i pozornie niedostrzegalnego. Młody człowiek zostaje przez Franciszka porównany do „ziemi świętej”, przed którą trzeba zdjąć sandały i wyruszyć w celu pogłębienia „Tajemnicy” w niej ukrytej (por. ChV 67). Każdy młody człowiek jest uczestnikiem tej Tajemnicy. Nie da się jednak uczynić tego bez empatii, tak koniecznej każdemu przewodnikowi, który w obliczu wielu dramatów młodych ma współodczuwać z nimi (por. ChV 75), wyrażając ten ból nawet przez formę współczującego płaczu (por. ChV 76). Dlatego właśnie ta bliskość jest istotna, chociaż często odstrasza koniecznością głębokiego zaangażowania i współodczuwania.

Konsekwencją empatii jest kolejny ważny aspekt duchowej sylwetki lidera, jakim jest język miłości. Papież zachęca do posługiwania się takim językiem, który jest

${ }^{27}$ FrancisZeK, ,Spotkanie z polskimi biskupami”, 36-7. 
rozumiany przez ludzi młodych ${ }^{28}$. Nie może być to mowa tylko karcąca, ale przede wszystkim mobilizująca do działania, która urzeczywistni przekaz kerygmatu w sposób przystępny dla młodego pokolenia (por. ChV 211). Oczywiście język miłości to nie tylko pobłażliwość, ale także obiektywna krytyka ludzi młodych (por. ChV 39).

Wiele uwagi papież Franciszek poświęca roli towarzyszenia młodym przez lidera. To towarzyszenie, rozumiane często jako obecność przy wzrastaniu duchowym, musi być poprzedzone poszukiwaniem, czyli wychodzeniem naprzeciw młodym ludziom dzięki działalności misyjnej w ich środowisku (por. ChV 209-210). Bardzo dobrze oddaje to przykład uczniów z Emaus (por. Łk 24, 13-35), który papież interpretuje, ukazując istotę tego problemu. W tym wybranym fragmencie ewangelii Jezus idzie z dwoma uczniami, którzy oddalają się od Jerozolimy i od wspólnoty. Chcąc im towarzyszyć, pielgrzymuje razem z nimi. Najpierw cierpliwie słucha, by rozpoznać, co przeżywają. Następnie interpretuje te wydarzenia w świetle Pisma Świętego, a gdy przemówił do ich serca, oni sami postanawiają bezzwłocznie nawrócić się, wrócić do wspólnoty i dzielić się doświadczeniem spotkania z Bogiem (por. $\mathrm{ChV}$ 237).

Te trzy wartości: słuchanie, język miłości i towarzyszenie powinny być udziałem każdego duchowego przewodnika, który - tak jak w ewangelicznym opowiadaniu ma asystować młodemu człowiekowi w drodze odkrywania Chrystusa. Ten trudny i zarazem delikatny proces nie powinien narzucać drogi, ale pozwalać im samym dostrzec Boże powołanie ${ }^{29}$.

\subsection{NIEBEZPIECZEŃSTWA W TOWARZYSZENIU MŁODZIEŻY}

Papież Franciszek, powołując się na przebieg Synodu Biskupów na temat młodzieży, zwraca uwagę na poruszaną w nim kwestię braku osób doświadczonych i oddanych posłudze towarzyszenia młodym. Potwierdza tym samym potrzebę przygotowania wykwalifikowanej kadry w posłudze młodzieży (por. ChV 244). Brak odpowiedniego doświadczenia, poświęcenia i umiejętności wycofania się, czyli czasu na osobistą formację, generują główne źródła problemów w tej dziedzinie ${ }^{30}$. Papież podkreśla, „że ci którzy nie wprowadzają do swoich terminarzy świętego czasu namysłu, zaczną w końcu kręcić się w kółko"31.

\footnotetext{
${ }^{28}$ EG 105; por. Marek FIAŁKOwSKI, „Papieża Franciszka inspiracje dla duszpasterstwa młodzieży”, 90.

${ }^{29}$ Marek FiaŁKowsKi, „Słuchanie i towarzyszenie. Wskazania papieża Franciszka dla współczesnego duszpasterstwa młodzieży", Społeczeństwo nr 2(146)(2019), 37.

${ }^{30}$ LowneY, Lider Papież Franciszek, 133.

${ }^{31}$ Lowney, Lider Papież Franciszek, 144.
} 
Franciszek przestrzega ponadto przed fałszywym przekonaniem, iż odpowiedzialni za formację należą do elitarnej grupy, która zna już wszystkie odpowiedzi na każde pytanie i która nie musi słuchać ani niczego się już uczyć. Taka postawa może doprowadzić lidera do klerykalizmu, gdy myli on pojęcie służby, którą należy ofiarować, z władzą, którą należy wypełniać. „Pragnienie panowania, braku dialogu i przejrzystości, formy podwójnego życia, pustka duchowa, a także kruchość psychiczna są przestrzenią, na której kwitnie demoralizacja" (ChV 98). Skutecznymi liderami można zostać nie przez wspinanie się po drabinie służbowej hierarchii, lecz przez to, że nasze czyny mówią same za siebie ${ }^{32}$.

Bez wątpienia klerykalizm naraża na utratę szacunku. Traktowanie służby jako władzy jest także powodem fałszywego obrazu współczesnej młodzieży, opartego wyłącznie na liście ich porażek i niedoskonałości. Lider nie może być ekspertem w znajdowaniu aspektów negatywnych, ponieważ taka postawa rodzi coraz większy dystans i zmniejsza bliskość relacji wychowawcy i podopiecznego (por. ChV 66). Papież Franciszek zauważa, że na młodych trzeba patrzeć ze zrozumieniem i miłością, a nie stale osądzać lub domagać się doskonałości, która jeszcze nie odpowiada ich wiekowi (por. ChV 243). Znajomość własnych wad i słabości pozwoli z większą wyrozumiałością patrzeć na drugiego człowieka. Nikt nie może być liderem, jeśli nie pozna własnych słabości i nie zmierzy się z nimi. Brak tej konfrontacji powoduje też brak autentyczności, która jest konieczna w byciu przywódcą ${ }^{33}$.

Wielkim wyzwaniem dla duszpasterzy jest także głęboka potrzeba autorytetu wśród młodzieży (por. ChV 99). Niestety bywają takie sytuacje, w których osoby, które powinny uchodzić za autorytet, nie są w stanie sprostać temu wyzwaniu. Czasami dorośli nie starają się lub nie potrafią przekazywać młodszej generacji podstawowych wartości życiowych lub przyjmują styl młodzieżowy, odwracając przy tym relacje międzypokoleniowe. Trudno w takiej sytuacji mówić o autorytecie, który staje się po prostu mało wiarygodny i dodatkowo znacznie utrudnia proces przekazywania wiary ${ }^{34}$. Nie można oczekiwać od młodzieży, że będzie się zachowywać w pewien sposób, skoro sami liderzy postępują inaczej ${ }^{35}$. Doświadczenie historyczne uczy, że większość najwybitniejszych liderów łączyła wspólna cecha, która stanowiła o posiadaniu pozytywnego, pewnego i przekonującego systemu wartości ${ }^{36}$.

\footnotetext{
${ }^{32}$ Por. Lowney, Lider Papież Franciszek, 45-7.

${ }^{33}$ Por. LownEY, Lider Papież Franciszek, 66.

${ }^{34} \mathrm{ChV}$ 80; por. Jan Guzowski, „Znaczenie autorytetu w życiu młodzieży”, w: Edukacja i formacja religijna wspótczesnej młodzieży. Problemy i wyzwania, red. Piotr Duksa (Olsztyn: Wydawnictwo Wyższego Seminarium Duchownego Metropolii Warmińskiej „Hosianum”, 2008), 131.

${ }^{35}$ Lowney, Lider Papież Franciszek, 56.

${ }^{36}$ TAYLOR, Lider bez maski, 28.
} 


\section{RELACJE Z BOGIEM}

\section{JAKO OWOC SPOTKANIA Z DRUGIM CZŁOWIEKIEM}

Współczesna filozofia personalistyczna podkreśla, że o osobie ludzkiej można mówić jedynie w relacji do innych osób, czyli inaczej mówiąc, w relacji z inny$\mathrm{mi}^{37}$. Relacyjność człowieka jest wpisana w strukturę jego bytu i ma dwa wymiary: horyzontalny, czyli ukierunkowany do życia we wspólnocie z ludźmi, oraz wertykalny, tzn. ukierunkowany do życia we wspólnocie z Bogiem ${ }^{38}$. Papież Franciszek potwierdza to w adhortacji Christus vivit, powołując się na słowa homilii św. Oscara Romero, że chrześcijaństwo nie jest tylko zbiorem wartości, praw czy nakazów, ale przede wszystkim jest relacją z Osobą, która umiłowała człowieka i która pragnie także odwzajemnienia tej miłości (por. ChV 156). Całe Objawienie ukazuje Boga jako przyjaciela człowieka. Przyjaźń ta jest wyrażona we wspólnocie, jaką Bóg nawiązuje z nim. Dlatego celem każdej osoby ludzkiej powinno być nawiązanie z Bogiem synowskiej relacji, która wyraża się we wspólnocie życia ${ }^{39}$.

Relacja z Bogiem sprawia, że młodzież na nowo odzyskuje chęć życia pełnego wigoru (por. ChV 20). Można niestety przeżyć młodość w rozkojarzeniu, prześlizgując się po powierzchni życia, bez pielęgnowania głębokich relacji, szukając zadowolenia i satysfakcji w dobrach materialnych (por. ChV 18-19). Papież Franciszek pragnie jednak udowodnić, jak wiele staje się możliwe, jeśli połączy się świeżość ludzi młodych i moc Boga (por. ChV 10). Potrzeba jednak odwagi, by zobaczyć, że więź z Bogiem wcale nie ogranicza człowieka. „Nie trzeba żałować, że przeżywa się młodość, będąc dobrym, otwierając serce Panu, żyjąc inaczej. Nic z tego nie odbiera nam młodości, ale ją umacnia i odnawia" (ChV 17). Związek z żywym Bogiem motywuje, pobudza i ukierunkowuje ku lepszemu życiu (por. ChV 138). Nie da się dotrzeć do głębi młodości, jeśli każdego dnia nie przeżywa się przyjaźni z Bogiem (por. ChV 150). Wychodząc z tego stwierdzenia, Franciszek porównuje relację z Nim do połączenia internetowego: ,[...] tak jak martwisz się, żeby nie stracić połączenia z Internetem, upewnij się, czy aktywne jest twoje połączenie z Panem, a to oznacza nieprzerywanie dialogu, słuchanie Go, opowiedzenie $\mathrm{Mu}$ o swoich sprawach" (ChV 158).

Zdaniem papieża Franciszka pocieszające jest to, że młodzież nadal odczuwa pragnienie Pana Boga, mimo że nie zawsze jest w stanie właściwie Go zdefiniować

\footnotetext{
${ }^{37}$ Andrzej Choromański, „Osoba ludzka jako «byt relacyjny» - antropologiczne fundamenty eklezjologii Soboru Watykańskiego II", Studia Teologii Dogmatycznej 1(2015), 72.

${ }^{38}$ Choromański, „Osoba ludzka”, 86.

${ }^{39}$ CHOromański, „Osoba ludzka”, 78.
} 
(por. ChV 84). Młodzież wyraża to pragnienie w marzeniu o braterstwie, rozwijaniu własnych zdolności, wrażliwości artystycznej oraz pragnieniu innego życia. Są to obszary, które należy wykorzystać w duszpasterstwie tak, aby ukazać im Boga jako miłującego Ojca (por. ChV 113). Według Franciszka siła młodości może być jednak uśpiona przez brak przeżywania wiary we wspólnocie. Niekiedy cała energia i entuzjazm młodych słabną przez pokusę zamknięcia się we własnych problemach, zranionych uczuciach, wygodach i narzekaniach (por. ChV 166). Z tego powodu zawsze lepiej jest przeżywać wiarę razem. Przyjaźń i relacje stwarzają okazję do dzielenia się wiarą i do wzajemnej pomocy w dawaniu świadectwa (por. ChV 219).

Kształtowanie relacji łączącej młodzież z Panem Bogiem jest możliwe wówczas, gdy horyzontalny wymiar tej relacji zostanie ukierunkowany w stronę wertykalnej relacji z Panem. Zasada korelacji, tzn. łączenia doświadczenia ludzkiego z Objawieniem Bożym, ma duże znaczenie pedagogiczno-religijne ${ }^{40}$. Należałoby w tym miejscu zwrócić uwagę na znaczący wpływ wychowania religijnego w procesie duchowego wzrostu młodzieży. Wiara jest łaską otrzymaną od Boga, co jednak nie wyklucza działania ze strony człowieka. Łaska implikuje naturę ludzką, budując na niej, a to z wychowawczego punktu widzenia może oznaczać podejmowanie określonych działań formacyjnych wspólnoty chrześcijan, przygotowujących innych do przyjęcia wiary, a następnie do jej rozwoju i dojrzewania ${ }^{41}$. Wychowanie do wiary pojawia się jako akt lub działanie mające charakter przygotowawczy, w pewnym sensie „propedeutyczny”, poprzedzający właściwą katechezę, a nawet proces ewangelizacji ${ }^{42}$. Wiara bowiem nie może się inaczej objawiać jak tylko w widzialnych aktach. Można więc powiedzieć, że wychowanie do wiary, jako proces przygotowania do niej, a więc i osobowej relacji z Bogiem, to na pierwszym miejscu troska o rozwój wartości ludzkich. Pierwszorzędne znaczenie w tym procesie zajmuje wspólnota osób wierzących, która jest gwarantem rozwoju religijnego ${ }^{43}$.

Z pewnością najlepszą wspólnotą zapewniającą wzrost, akceptację oraz możliwość pogłębionej relacji z Bogiem jest Kościół. Papież Franciszek wyraża jednak swoje ubolewanie, że niestety nie zawsze jest on dla młodzieży czymś istotnym w życiu. Niektórzy odczuwają jego obecność jako uciążliwą, co ma swoje korzenie w poważnych przyczynach: ,skandalach seksualnych i ekonomicznych,

\footnotetext{
${ }^{40}$ Zygmunt KLIMCZuK, „Przekazywanie wiary w rodzinie”, w Edukacja i formacja religijna wspótczesnej młodzieży, 12.

${ }^{41}$ Kazimierz Misiaszek, „Wychowanie do wiary”, w Autorytet prawdy. Wychowanie dzieci i młodzieży, red. Maria Ryś (Warszawa: Wydawnictwo Uniwersytetu Kardynała Stefana Wyszyńskiego, 2006), 113.

42 MisiaczeK, „Wychowanie do wiary”, 111.

${ }^{43}$ MisiaczeK, „Wychowanie do wiary”, 116.
} 
nieprzygotowaniu kapłanów, którzy nie potrafią odpowiednio uchwycić wrażliwości młodych ludzi; braku staranności w przygotowaniu homilii i głoszeniu słowa Bożego; bierności przypisywanej ludziom młodym we wspólnocie chrześcijańskiej; trudnościom Kościoła w uzasadnianiu swojego stanowiska doktrynalnego i etycznego wobec współczesnego społeczeństwa" (ChV 40).

Brak odpowiedniego środowiska wiary nie doprowadzi młodych do relacji z Bogiem. Dlatego papież Franciszek nawołuje, by bardziej rozwijać i umacniać takie wspólnoty, jak rodzina, szkoła czy parafia, które powinny „oferować drogi bezinteresownej miłości i promocji, afirmacji i rozwoju" (ChV 216). Zwłaszcza w rodzinie następuje pierwsza religijna socjalizacja, dlatego jest to środowisko kluczowe dla elementarnego wychowania religijnego. Efektywność życia religijnego w rodzinie wpływa na jakość wychowania w wierze młodzieży i kreowania ich relacji z Bogiem ${ }^{44}$. Brak ciągłości, eliminowanie podstawowych wartości, którym sprzyja obecna kultura medialna, powodują wśród młodzieży poczucie głębokiego osierocenia, na które trzeba odpowiedzieć przez tworzenie przestrzeni braterskich (por. ChV 216).

Właściwe relacje międzyludzkie są prawdziwym odbiciem Boga, jak poucza Pismo Święte: ,pociągnąłem ich ludzkimi więzami, a były to więzy miłości” $(\mathrm{Oz} 11,4)$. Przyjaźń, zdaniem Franciszka, jest darem Stwórcy. Poprzez przyjaciół Pan Bóg sprawia, że człowiek dojrzewa. Mając bliskich przyjaciół, człowiek jednocześnie uczy się także postaw otwierania się, zrozumienia, troski o innych oraz wyjścia z izolacji i dzielenia życia z innymi (por. ChV 151). Odkrywanie własnej tożsamości jest możliwe dzięki relacjom z innymi wewnątrz różnych społeczności i wspólnot ${ }^{45}$. Wertykalny charakter więzi z Bogiem zachodzi więc dzięki tym poszczególnym relacjom wspólnotowym. Niezbywalnym również składnikiem ludzkiej tożsamości staje się odniesienie do Boga Ojca, ku któremu ma zmierzać wspólny wysiłek wychowania w rodzinach, szkołach i organizacjach społecznych ${ }^{46}$.

Wielu ludzi młodych jest zdolnych do prawdziwej zażyłości z Bogiem. W przekonaniu papieża Franciszka są na to konkretne sposoby, które - dzięki duszpasterskiej refleksji i aktualizacji do lokalnych wspólnot - zdołają pogłębić te relacje. Proces formacji młodzieży należy zaczynać od refleksji dotyczącej oddawania czci Bogu i modlitwy. Nie wolno zakładać, iż młodzież nie jest zdolna otworzyć się

\footnotetext{
${ }^{44}$ KLimczuK, „Przekazywanie wiary w rodzinie”, 12-13.

${ }^{45}$ ChoromańsKi, „Osoba ludzka”, 74.

${ }^{46}$ Stanisław SŁAwIŃSKI, „O wspólny kierunek wychowania”, w Autorytet prawdy. Wychowanie dzieci i młodzieży, red. Maria Ryś (Warszawa: Wydawnictwo Uniwersytetu Kardynała Stefana Wyszyńskiego, 2006), 11.
} 
na propozycje kontemplacyjne. Trzeba znaleźć odpowiednie style i sposoby, aby młodzi mogli wejść w doświadczenie głębokiej relacji z Panem (por. ChV 224). „W różnych kontekstach młodzi katolicy domagają się propozycji modlitewnych i wydarzeń sakramentalnych, zdolnych do przemieniania ich życia powszedniego w świeżą, autentyczną i radosną liturgię" (ChV 224). Istotną rolę może odegrać również odpowiednie wykorzystanie roku liturgicznego, m.in. do organizowania radosnych spotkań świątecznych przełamujących rutynę i pomagających doświadczyć radość wiary. Wykorzystując zainteresowanie ludzi młodych duchowością, trzeba starać się zauważać i z otwartością przyjmować oddolne inicjatywy młodzieży, w których pragną oni wyrażać swoją wiarę ${ }^{47}$.

Szczególną okazją do rozwoju więzi z Bogiem jest także służba bliźniemu, w której młodych pociąga możliwość pomocy innym, zwłaszcza ubogim (por. ChV 225). Często ta posługa, jak zauważa Franciszek, jest pierwszym krokiem do odkrycia głębi życia chrześcijańskiego i kościelnego. To dzięki niej formacja młodzieży staje się nie tylko doktrynalna, lecz także duchowa. Służba wyrażona w pełnieniu czynów miłosierdzia jest odzwierciedleniem wizerunku Chrystusa, ukazywaniem Jego miłości wobec każdego człowieka. Taki wymiar służby umożliwia poznanie Boga osobowego, który znajduje swoje odbicie w potrzebujących pomocy oraz w tych, którzy im posługują ${ }^{48}$. W budowaniu relacji młodzieży z Bogiem nie można pominąć form artystycznego wyrazu, takich jak teatr, malarstwo itp. Trzeba także uwzględnić ogromną wartość muzyki, w której młodzi są mocno zagłębieni. Język muzyki jest zdolny do budzenia emocji, kształtowania tożsamości, a ponadto powinien stać się źródłem duszpasterskiej odnowy liturgii, w której śpiew może okazać się wielkim bodźcem na drodze komunikacji z Bogiem (por. ChV 226).

Uprawianie sportu stanowi również duży potencjał wychowawczy i formacyjny ludzi młodych, którego Kościół nie powinien lekceważyć i w którym powinien być zdecydowanie obecny. W przekonaniu papieża Franciszka, „u podstaw tego doświadczenia sportowego jest «radość: radość poruszania się, radość bycia razem, radość z powodu życia i darów, które Stwórca daje nam każdego dnia»" (ChV 227). Sport uczy samodyscypliny, wytrwałości, poświęcenia, znoszenia przeciwności. Okazuje się, że nie są to cnoty tylko i wyłącznie zarezerwowane dla świata sportu, ale przydają się także w kształtowaniu charakteru młodego chrześcijanina.

Jeden z ostatnich obszarów rozwoju duszpasterstwa młodych, który docenia papież w adhortacji Christus vivit, dotyczy kontaktu ludzi młodych ze światem

\footnotetext{
${ }^{47}$ Marek FiaŁkowsKi, „Papieża Franciszka inspiracje dla duszpasterstwa młodzieży”, 94.

${ }^{48}$ Por. Wiesław PrzYGODA, ,Apostolski wymiar wolontariatu młodzieży na przykładzie Szkolnych Kół Caritas”, Warszawskie Studia Pastoralne nr 2(23)(2014), 229-50.
} 
stworzonym i ich wrażliwości na ochronę środowiska (por. ChV 228). Przykład harcerzy i innych grup organizujących kampingi, wędrówki, wyprawy może prowadzić do doświadczenia powszechnego braterstwa i modlitwy kontemplacyjnej, w myśl słów: „Bo z wielkości i piękna stworzeń poznaje się przez podobieństwo ich Stwórcę" (Mdr 13, 5).

Na koniec swoich przemyśleń zawartych $\mathrm{w}$ adhortacji Christus vivit Franciszek przypomina także o tych obszarach, które powinny być zawsze aktualne. Najpierw wymienia słowo Pana, przekraczające wszystkie epoki, żywe i skuteczne, ukazujące różne Jego miłujące oblicza wobec młodych (por ChV 114). Obecność Chrystusa w Eucharystii, która wzmacnia i posila, a także uwalniający od grzechu sakrament pokuty i pojednania, są również niezbywalnymi metodami duszpasterstwa młodzieży. Nie zostaje także pominięte niewyczerpane bogactwo duchowe Kościoła w świadectwach świętych oraz nauczania mistrzów duchowych. Są to elementy formacji, do których na pewno dochodzi się w cierpliwym procesie dojrzewania duchowego i w żadnym stopniu nie można pozbawiać ich młodzieży (por. ChV 229).

Dynamizm postępujących zmian społeczno-kulturowych wymusza ciągłą aktualizację duszpasterstwa. Nie da się stworzyć jednolitego i zawsze obowiązującego programu duszpasterskiego, który zaspokoi raz na zawsze wszelkie potrzeby wszystkich grup ludzi. Szukanie rozwiązania nie powinno też polegać na wynajdywaniu nowości i nowinek duszpasterskich, ale na ciągłym ulepszaniu jakości dotychczasowej pracy, której stale grozi rutyna i schematyczność. Najlepszy program to ten, który rozpoznaje zapotrzebowanie danej grupy i w świetle ewangelii szuka najwłaściwszych rozwiązań.

Niewątpliwie współczesna młodzież ma swoje wielorakie problemy, ale także potrzeby religijno-duchowe oraz związane z nimi wymagania duszpasterskie. Toteż duszpasterstwo młodzieży adekwatne do współczesnych wyzwań powinno opierać się na dojrzałych, opartych na głębokim autorytecie relacjach osobowych. Oczywiście, trzeba wziąć pod uwagę wszelkie środki ostrożności, które zaleca Kościół w trosce o dobro młodego pokolenia, a także osób za nich odpowiedzialnych ${ }^{49}$,

\footnotetext{
${ }^{49}$ Por. Instrukcje poszczególnych biskupów diecezjalnych na temat przeciwdziałania wykorzystywaniu nieletnich w kontekście duszpasterstwa młodzieży, np. „Zasady ochrony małoletnich i niepełnosprawnych w praktyce wychowawczo-duszpasterskiej Archidiecezji Łódzkiej”, https://ekai.pl/ wp-content/uploads/2019/05/Zasady-ochrony-ma\%C5\%82oletnich-2.pdf, 1-88 [dostęp: 02.04.2020]; „Ochrona małoletnich w działaniach duszpasterskich Diecezji Tarnowskiej - normy i zasady”, https:// www.diecezja.tarnow.pl/images/do_pobrania/ochrnieldtarnowska.pdf, 1-35 [dostęp: 02.04.2020].
} 
w celu tworzenia takich więzi, które ukierunkują środowisko młodzieży na głęboką relację z Bogiem osobowym.

Adhortacja apostolska Christus vivit papieża Franciszka bardzo dobrze wpisuje się w zapotrzebowanie duszpasterskie obecnych czasów. Zawiera ona konkretną, nieodrealnioną, wizję duszpasterstwa młodzieży. Franciszek z odwagą i precyzją analizuje obecną sytuację młodego pokolenia, zachęcając je do pogłębionej relacji z Bogiem bez pomijania dojrzałych i pięknych więzi międzyludzkich.

\section{BIBLIOGRAFIA}

BAKIERA, Lucyna i Barbara Harwas-NAPIERAla. Wzory osobowe w rozwoju człowieka. Poznań: Wydawnictwo Naukowe UAM, 2016

BAŁANDYNOwICZ, Andrzej. „Cyberprzestrzeń jako facylitacja degeneratywnych zachowań młodzieży”. W: Młodzi. Przeciw czemu się buntują? Czego pragną? Co budują?, red. Łukasz Kwadrans, Ewa Sowa-Behtane i Bogdan Stańkowski, 173-89. Kraków: Wydawnictwo Naukowe Akademii Ignatianum, 2018.

Burns, Jim. Owocna posługa wśród młodzieży. Czyli jak towarzyszyć młodym, tł. Krzysztof Zabawa. Gubin: Wydawnictwo Przystanek Jezus, 2017.

CHOromański, Andrzej. „Osoba ludzka jako «byt relacyjny» - antropologiczne fundamenty eklezjologii Soboru Watykańskiego II". Studia Teologii Dogmatycznej 1(2015): 58-87.

FiaŁKowsKi, Marek. „Papieża Franciszka inspiracje dla duszpasterstwa młodzieży”. Polonia Sacra 20, $\operatorname{nr} 4$ (2016): 87-99.

FIAŁKowski, Marek. „Słuchanie i towarzyszenie. Wskazania papieża Franciszka dla współczesnego duszpasterstwa młodzieży”. Społeczeństwo nr 2(146)(2019): 29-39.

FRANCISZEK. Adhortacja apostolska Evangelii gaudium. Kraków: Wydawnictwo M, 2013.

FRANCISZEK. Błogosławieni miłosierni. Słowa do młodych. Kraków: Wydawnictwo M, 2016.

FranciszeK. Posynodalna adhortacja apostolska Christus vivit. Kraków: Wydawnictwo M, 2019.

GŁowACKI, Antoni. „Religijność młodzieży i uczestnictwo w lekcjach religii w szkołach. Komunikat z badań CBOS nr 43/2019”. W Młodzież 2018, red. Mirosława Grabowska i Magdalena Gwiazda, Warszawa: CBOS, 2019.

Guzowski, Jan. „Znaczenie autorytetu w życiu młodzieży”. W Edukacja i formacja religijna wspótczesnej młodzieży. Problemy $i$ wyzwania, red. Piotr Duksa, 129-43. Olsztyn: Wydawnictwo Wyższego Seminarium Duchownego Metropolii Warmińskiej „Hosianum”, 2008.

Herberger, Jerzy i Monika KozŁowsKA. „Relacje interpersonalne z perspektywy psychologii rozwoju człowieka". Relacje. Studia z Nauk Społecznych nr 4 (2017): 35-48.

KARMOLIŃSKA-JAGODZIK, Ewa. „Przestrzeń międzygeneracyjna - relacje młodzieży z rodzicami”. Studia Edukacyjne nr 47(2018): 289-311.

KLimczuk, Zygmunt. „Przekazywanie wiary w rodzinie”. W Edukacja i formacja religijna współczesnej młodzieży. Problemy i wyzwania, red. Piotr Duksa, 5-19. Olsztyn: Wydawnictwo Wyższego Seminarium Duchownego Metropolii Warmińskiej „Hosianum”, 2008.

LIPIEC, Dariusz. „Marketing a duszpasterstwo”. Teologia Praktyczna 16(2015): 7-20.

Lowney, Chris. Lider Papież Franciszek, tł. Marek Chojnacki, Kraków: Wydawnictwo WAM, 2014. MARIAŃSKI, Janusz. Żyć parafią. Wrocław: Wydawnictwo Wrocławskiej Księgarni Archidiecezjalnej, 1984 MisiaszeK, Kazimierz. „Wychowanie do wiary”. W Autorytet prawdy. Wychowanie dzieci i mtodzieży, red. Maria Ryś, 105-21. Warszawa: Wydawnictwo Uniwersytetu Kardynała Stefana Wyszyńskiego, 2006. 
PrzyGODA, Wiesław. „Apostolski wymiar wolontariatu młodzieży na przykładzie Szkolnych Kół Caritas". Warszawskie Studia Pastoralne nr 2(23)(2014): 229-50.

PrZyGODA, Wiesław. „Wolontariat w służbie solidaryzmu społecznego dzieci i młodzieży”. Zeszyty Formacji Katechetów nr 4(2017): 29-36.

Roguska, Beata. „Dom rodzinny, rodzice i rówieśnicy w opiniach młodego pokolenia Polaków. Komunikat z badań CBOS nr 43/2019". W Młodzież 2018, red. Mirosława Grabowska i Magdalena Gwiazda. Warszawa: CBOS, 2019.

RUDNIK, Anna. „Relacje międzypokoleniowe w rodzinie - perspektywa gerontologiczna”. W Relacje międzypokoleniowe we współczesnych polskich rodzinach, red. Piotr Szukalski, 41-55. Łódź: Wydawnictwo Uniwersytetu Łódzkiego, 2014.

SŁAwIŃSKI, Stanisław. „O wspólny kierunek wychowania”. W Autorytet prawdy. Wychowanie dzieci i młodzieży, red. Maria Ryś, 9-21. Warszawa: Wydawnictwo Uniwersytetu Kardynała Stefana Wyszyńskiego, 2006.

ŚwIĘS, Kazimierz. „Uwarunkowania duszpasterstwa parafialnego w Polsce na początku XXI wieku”. Teologia i Człowiek nr 3(2019): 73-90.

TAYLOR, David. Lider bez maski. Prawdziwa droga do sukcesu, tł. M. Werbanowska. Warszawa: Wolter Kluwer Polska, 2009.

Wolicki, Marian. Relacje osobowe. Sandomierz: Wydawnictwo Diecezjalne i Drukarnia, 2008.

\section{RELACJA OSOBOWA NARZĘDZIEM DUSZPASTERSTWA MŁODZIEŻY NA PODSTAWIE ADHORTACJI APOSTOLSKIEJ CHRISTUS VIVIT PAPIEŻA FRANCISZKA}

\section{Streszczenie}

W obecnych czasach wciąż aktualnym wyzwaniem Kościoła jest troska o duszpasterstwo młodego pokolenia. Tę pilną potrzebę zauważył również papież Franciszek w adhortacji apostolskiej Christus vivit. Na podstawie tego dokumentu można opracować konkretną strategię duszpasterską w pracy z młodzieżą. W opinii papieża troska o młodych powinna wyrażać się w głębokich, osobowych relacjach zbudowanych na prawdziwym autorytecie. Istotnym czynnikiem w procesie formacji chrześcijańskiej jest rola odpowiedniego lidera oraz wspólnoty, która tworząc środowisko wiary, doprowadza do spotkania z Bogiem. Człowiek jest istotą relacyjną. Dlatego, dzięki relacjom z innymi osobami, można doprowadzić go do spotkania z Panem. Troska o młodych nie jest zadaniem zarezerwowanym dla jednostek, ale dla wszystkich środowisk, które wywierają wpływ na postawę młodych ludzi. Tylko dzięki zaangażowaniu wszystkich będzie możliwe trwałe i skuteczne duszpasterstwo młodzieży.

Słowa kluczowe: młodzież; Christus vivit; relacja osobowa; duszpasterstwo; lider; wychowanie; rodzina; relacje międzypokoleniowe. 